\title{
Sensitivity of Phytophthora nicotianae From Tobacco to Fluopicolide, Mandipropamid, and Oxathiapiprolin
}

Tianli Qu, Department of Plant Pathology, University of Georgia, Tifton, GA 31794, and Chemistry and Pharmacy College, Qingdao Agricultural University, Shandong 266109, China; Yuanyuan Shao, Department of Plant Pathology, University of Georgia and College of Agriculture, Guangxi University, Guangxi 530004, China; and Alexander S. Csinos and Pingsheng Ji, Department of Plant Pathology, University of Georgia, Tifton, GA 31794

\begin{abstract}
Qu, T., Shao, Y., Csinos, A. S., and Ji, P. 2016. Sensitivity of Phytophthora nicotianae from tobacco to fluopicolide, mandipropamid, and oxathiapiprolin. Plant Dis. 100:2119-2125.

Black shank incited by Phytophthora nicotianae is a devastating disease in the production of tobacco. Fungicides have been commonly used for managing the disease; however, there is only a narrow pool of effective fungicides. A few new fungicides became available in recent years, including fluopicolide, mandipropamid, and oxathiapiprolin, which reduced diseases incited by oomycetes under field conditions. Limited information is available regarding sensitivity of $P$. nicotianae isolates to these new fungicides. Research was conducted to determine effects of the three new fungicides on $P$. nicotianae isolates from tobacco in Georgia. Studies with 106 isolates indicated that they did not grow when agar medium was amended with the fungicides at the rate of $1 \mu \mathrm{g} / \mathrm{ml}$. Twenty isolates were used for in vitro studies to determine sensitivity to the fungicides. Fluopicolide, mandipropamid, and oxathiapiprolin

inhibited mycelial growth of the isolates with mean $\mathrm{EC}_{50}$ values (effective concentrations that provide $50 \%$ growth reduction) of $0.09,0.04$, and $0.001 \mu \mathrm{g} / \mathrm{ml}$, respectively. $\mathrm{EC}_{50}$ values of fluopicolide, mandipropamid, and oxathiapiprolin for inhibiting sporangial formation were $0.15,0.03$, and $0.0002 \mu \mathrm{g} / \mathrm{ml}$, respectively. $\mathrm{EC}_{50}$ values for suppressing zoospore germination averaged $0.16,0.04$, and $0.002 \mu \mathrm{g} / \mathrm{ml}$ for fluopicolide, mandipropamid, and oxathiapiprolin, respectively. Results from the study indicated that $P$. nicotianae isolates from tobacco in Georgia were sensitive to the fungicides, with lower $\mathrm{EC}_{50}$ for oxathiapiprolin than for fluopicolide and mandipropamid. The information on effectiveness and baseline sensitivity of fungicides on $P$. nicotianae will facilitate monitoring of resistance development in the pathogen population.
\end{abstract}

Black shank is a soilborne disease that can kill and significantly reduce yield of tobacco (Nicotiana tabacum L.) in major tobaccoproducing regions of the world (Lucas 1975; Shew and Lucas 1998). The disease is initiated by Phytophthora nicotianae (Breda de Haan) that was also named Phytophthora parasitica var. nicotianae (Erwin and Ribeiro 1996; Shew and Lucas 1998). In the United States, the disease was first identified in the 1910s in Georgia and is now known to be distributed in all major tobacco-producing areas in the country (Csinos and Bertrand 1994; Lucas 1975; Mila and Radcliff 2008; Shew and Lucas 1998). Typical symptoms of infected tobacco plants include stunting, leaf chlorosis, and black lesions on lower stems (Shew and Lucas 1998). The disease is characterized by the pith becoming plate-like disks that turn black or brown. Infected roots may become blackened and plants may wilt and die eventually.

Phytophthora nicotianae produces asexual spores including sporangia and zoospores that play important roles in infection of plants and disease development (Erwin and Ribeiro 1996; Shew and Lucas 1998). Sporangia may be produced on mycelia in infected plant tissues that can germinate to form germ tubes for infection or produce zoospores. Zoospores are attracted by plant tissues, and they may germinate quickly and initiate infection under favorable environmental conditions (Erwin and Ribeiro 1996; Shew and Lucas 1998). Sporangia and zoospores may be dispersed by wind, splashing water, or surface water and contribute significantly to dispersal, infection of new plants, and epidemics of the disease. Hence, measures can be taken to eliminate or reduce production or germination of the spores of the pathogen to reduce the disease.

Strategies recommended for managing black shank include resistant tobacco cultivars and applications of fungicides (Antonopoulos

Corresponding author: P. Ji; E-mail: pji@uga.edu

Accepted for publication 20 May 2016

http://dx.doi.org/10.1094/PDIS-04-16-0429-RE

(C) 2016 The American Phytopathological Society et al. 2010; Csinos and Minton 1983). Some commercial cultivars of tobacco are resistant to race 0 of $P$. nicotianae, which occurs most commonly. However, race 1 populations of the pathogen that are aggressive on the tobacco cultivars resistant to race 0 have been reported in some tobacco-producing areas, including Georgia (Csinos and Bertrand 1994; Parkunan et al. 2010). Applications of fungicides are generally used by growers to manage the different races of the pathogen. Metalaxyl and its active ingredient mefenoxam have been used in the past decades for managing black shank. Although P. nicotianae isolates from tobacco resistant to mefenoxam have not been reported, it is risky to use a single fungicide continuously, which might enhance development of $P$. nicotianae strains resistant to the fungicide (Shew 1985). In recent years, several new fungicides became available that provided excellent suppression of black shank. Among the new fungicides, fluopicolide and mandipropamid reduced blank shank significantly (Johnson 2015; Mila and Radcliff 2013), and application of fluopicolide in conjunction with mandipropamid was more effective than mefenoxam in reduction of the disease (Mila and Radcliff 2013). Repeated field experiments conducted in the southeastern United States in recent years indicated that black shank was reduced significantly by oxathiapiprolin and tobacco yield was increased (Bittner and Mila 2016; Ji et al. 2014; Johnson 2015).

It is evident that the new fungicides are effective in suppression of black shank; however, limited information is available about sensitivity of different life stages of the pathogen to the fungicides. This research was conducted to determine effects of fluopicolide, mandipropamid, and oxathiapiprolin on different life stages of $P$. nicotianae isolated in Georgia from tobacco. Information regarding sensitivity of the pathogen to the fungicides will facilitate monitoring potential fungicide resistance development and guide development of more effective programs for managing black shank by alternated applications of fungicides with different modes of action.

\section{Materials and Methods}

Phytophthora nicotianae isolates. Tobacco plants showing symptoms of black shank were sampled from 20 commercial fields in six counties of Georgia in 2013 and 2014 (Fig. 1). Lower stem tissues ( $2 \mathrm{~cm}$ long) were soaked in $0.5 \% \mathrm{NaOCl}$ for $60 \mathrm{~s}$ and were triple-rinsed with 
sterile distilled water (SDW). The tissues were air-dried in an aseptic hood, and a piece of stem tissue from the advancing margin of the lesion was placed on a 9-cm-diameter pimaricin-ampicillinrifampicin-pentachloronitrobenzene-hymexazol (PARPH) agar plate (Parkunan and Ji 2013). After incubation at $25^{\circ} \mathrm{C}$ for 5 days, fungallike colonies growing from the stem tissues were transferred to PARPH agar plates by hyphal-tip subculturing. The isolates were then purified by subculturing hyphal tips on $10 \%$ V8 plates.

Sterile soil extract (SSE) was prepared as described previously and was used for inducing zoospore production by the isolates (Hu et al. 2007). Mycelial plugs (1 cm diameter) taken from the margin of 7-day-old cultures on V8 plates were transferred to $10 \mathrm{ml}$ of SSE in 6 -cm diameter petri dishes. The dishes were incubated under continuous light at 22 to $23^{\circ} \mathrm{C}$ for 2 days. SSE in the dishes was then replaced by $10 \mathrm{ml}$ of SDW. After chilling $\left(4^{\circ} \mathrm{C}\right)$ for $35 \mathrm{~min}$, the dishes were incubated at 22 to $23^{\circ} \mathrm{C}$ for $25 \mathrm{~min}$. Zoospore suspensions were transferred to sterile 50-ml capacity plastic tubes and were vortexed for $30 \mathrm{~s}$ to encyst zoospores. Single zoospore isolates were prepared by the methods reported previously (Yin et al. 2012).

For further confirmation of the identity of the pathogen, genomic DNA was extracted from mycelia of 10-day-old cultures of the isolates, using DNeasy plant mini kit (Qiagen, Valencia, CA) according to the manufacturer's instructions. Polymerase chain reaction (PCR) was conducted in $25-\mu \mathrm{l}$ mixtures with $1.5 \mu \mathrm{l}$, each, of the $P$. nicotianaespecific primers Pn1 and Pn2 $(10 \mu \mathrm{M}), 0.2 \mu \mathrm{l}$ of Taq polymerase (1 unit), $2.5 \mu \mathrm{l}$ of buffer (10x), $0.5 \mu \mathrm{l}$ of dNTP (10 mM), and $2 \mu \mathrm{l}$ of template DNA $(50 \mathrm{ng} / \mu \mathrm{l})$. PCR reaction was conducted and PCR products detected using the conditions reported previously (Meng and Wang 2010).

Pathogenicity assays. Sand was purchased from a local supplier, was moistened with distilled water, and was autoclaved for $45 \mathrm{~min}$ at $121^{\circ} \mathrm{C}$ on two consecutive days. Sand was mixed with potting mix
(Scotts Miracle-Gro Co., Marysville, $\mathrm{OH}$ ) at 1:2 ratio (vol/vol). Tobacco seeds (cv. K326) were sown in 10-cm-diameter pots $(450 \mathrm{ml}$ capacity) containing the soil mix in a greenhouse. Seedlings were transplanted to seedling trays with cells $(3.6 \times 3.6 \times 6.0 \mathrm{~cm})$ containing the soil mix 3 weeks after seeding, one plant per cell. Isolates of $P$. nicotianae mentioned above were grown on $\mathrm{V} 8$ plates at $25^{\circ} \mathrm{C}$ for 10 days in darkness. A mycelial plug $(0.7 \mathrm{~cm})$ from the advancing margin of the colonies was transferred to a V8 agar plate. Wheat grains were soaked in distilled water for $6 \mathrm{~h}$ and were autoclaved $\left(121^{\circ} \mathrm{C}\right.$ ) for $30 \mathrm{~min}$ on 2 consecutive days. Autoclaved grains were placed on the V8 agar plates with the mycelial plugs, 50 grains per plate. After incubating at $25^{\circ} \mathrm{C}$ for 10 days, wheat grains on the plates were used for inoculation. Tobacco seedlings were inoculated one week after transplanting by placing two wheat grains under the soil surface around each plant. Six plants were inoculated with each isolate, and six plants treated with autoclaved wheat grains were used as a control. The plants were kept in the greenhouse at $20^{\circ} \mathrm{C}$ (night) to $30^{\circ} \mathrm{C}$ (day). Disease incidence (\% diseased plants) was evaluated weekly until 3 weeks after inoculation. The experiment was conducted twice under the same conditions. At the end of the experiments, three diseased plants were taken from each treatment for isolation and identification of causal agents of the disease, as described above.

Inhibition of mycelial growth by the fungicides. A collection of 106 isolates identified to be $P$. nicotianae was used in the study. Technical grade mandipropamid (Sigma-Aldrich, St. Louis), fluopicolide, and oxathiapiprolin (provided by Valent USA, Walnut Creek, CA, and DuPont USA, Wilmington, DE, respectively) was dissolved in acetone to make stock solutions. V8 agar was autoclaved and cooled to $50^{\circ} \mathrm{C}$, and the stock solutions were used to amend the medium at final fungicide concentrations of 1 and $5 \mu \mathrm{g} / \mathrm{ml}$. A mycelial plug $(0.7 \mathrm{~cm}$ diameter) from the advancing margin of the colonies of

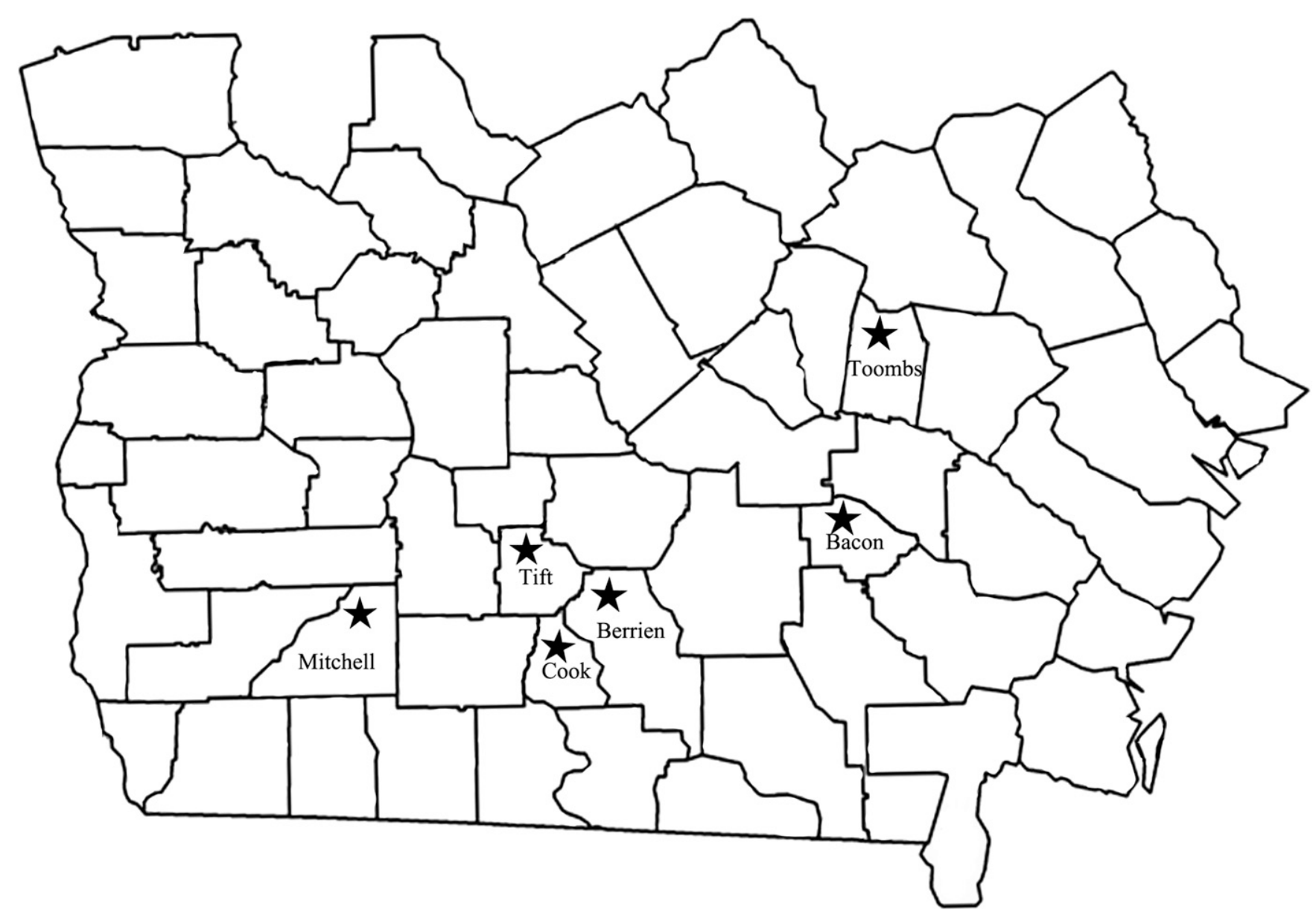

Fig. 1. Distribution of sampling sites in south Georgia. Sampling sites are marked using star symbol. 
10-day-old $P$. nicotianae cultures was transferred to V8 plates amended with the fungicides, three plates for each treatment (i.e., each concentration of the fungicides for each isolate). Three plates amended with acetone only were used as a control for each isolate. After incubation at $25^{\circ} \mathrm{C}$ for 7 days in the dark, the plates were observed, to determine growth of the cultures.

Twenty isolates, one from each field sampled, were selected to evaluate sensitivity of $P$. nicotianae to the three fungicides. V8 plates were amended with the fungicides to achieve final concentrations of $0.05,0.1,0.25,0.5$, and $1.0 \mu \mathrm{g} / \mathrm{ml}$ for fluopicolide, $0.01,0.05,0.1$, $0.25,0.5$, and $1.0 \mu \mathrm{g} / \mathrm{ml}$ for mandipropamid, and $0.0001,0.00025$, $0.0005,0.001,0.005$, and $0.01 \mu \mathrm{g} / \mathrm{ml}$ for oxathiapiprolin. Isolates were grown, transferred, and incubated under conditions as described above. Three fungicide-amended plates were used for each treatment as well as three plates amended with acetone only as controls. Colony diameters were measured and effective concentrations that provide $50 \%$ growth reduction $\left(\mathrm{EC}_{50}\right)$ were calculated by fitting linear regression lines of probit-transformed inhibition data against the $\log 10$ transformed fungicide concentration (Koné et al. 2009; Stein and Kirk 2003). Two repeated experiments were conducted, and results of the experiments were pooled with mean $\mathrm{EC}_{50}$ and standard errors calculated.

Inhibition of sporangium formation by fungicides. The 20 isolates were incubated at $25^{\circ} \mathrm{C}$ for 10 days in darkness. Three mycelial plugs $(1 \mathrm{~cm}$ diameter) from the advancing edge of the cultures were placed in a petri dish $(6 \mathrm{~cm})$ containing $10 \mathrm{ml}$ of SSE amended with the fungicides. The fungicides were prepared as mentioned above and final concentrations of the fungicides used were $0.1,0.25,0.5$, $1.0,2.5$, and $5.0 \mu \mathrm{g} / \mathrm{ml}$ for fluopicolide, $0.01,0.025,0.05,0.1,0.5$, and $1.0 \mu \mathrm{g} / \mathrm{ml}$ for mandipropamid, and 0.0001, 0.00025, 0.0005, $0.001,0.005$, and $0.01 \mu \mathrm{g} / \mathrm{ml}$ for oxathiapiprolin. Three petri dishes were used for each treatment, and three dishes with SDW amended with acetone only were used as a control. After incubating at $25^{\circ} \mathrm{C}$ for $48 \mathrm{~h}$ under artificial fluorescent light, the mycelial plugs were stained with acid fuchsin (Matheron and Porchas 2000). The agar plugs were observed under a stereo microscope $(100 \times)$ and numbers of sporangia under three microscopic fields were counted for each plug. Two repeated experiments were conducted, and results from the experiments were combined to calculate $\mathrm{EC}_{50}$ values.

Inhibition of zoospore germination by fungicides. Preparation of zoospore suspensions of the 20 isolates was as described above by soaking agar plugs $(1 \mathrm{~cm})$ in SSE and chilling at $4^{\circ} \mathrm{C}$ to induce zoospore release. Zoospore suspension $\left(100 \mu \mathrm{l}, 2 \times 10^{3}\right.$ spores per milliliter) was spread plated on a fungicide-amended V8 plate. Final fungicide concentrations were $0.1,0.25,0.5,1.0$, and $5.0 \mu \mathrm{g} / \mathrm{ml}$ for fluopicolide, $0.01,0.025,0.05,0.1$, and $0.5 \mu \mathrm{g} / \mathrm{ml}$ for mandipropa$\mathrm{mid}$, and $0.0001,0.00025,0.0005,0.001,0.005$, and $0.01 \mu \mathrm{g} / \mathrm{ml}$ for oxathiapiprolin. Three plates were used for each treatment and three plates amended with acetone only were used as a control. The number of zoospores that germinated per 100 spores examined on each plate was recorded after incubation for 5 to $6 \mathrm{~h}$ at $25^{\circ} \mathrm{C}$. Two repeated experiments were conducted and results of the experiments were pooled to calculate mean $\mathrm{EC}_{50}$ and standard errors.

\section{Results}

Phytophthora nicotianae isolates. The 106 isolates were identified to be $P$. nicotianae. PCR amplification using primers $\mathrm{Pn} 1$ and Pn2 yielded a 389-bp product from all the isolates. When the isolates were used for inoculation of tobacco seedlings in the greenhouse, all the isolates caused disease with 83.3 to $100 \%$ of the infected plants 3 weeks after inoculation.

Inhibition of mycelial growth by fungicides. All 106 isolates of $P$. nicotianae were sensitive to fluopicolide, mandipropamid, and oxathiapiprolin, since none of them could grow on V8 agar amended with the compounds at 1 or $5 \mu \mathrm{g} / \mathrm{ml}$. When tested at lower concentrations of the fungicides with 20 selected isolates, they were more sensitive to oxathiapiprolin than to fluopicolide or mandipropamid. Fluopicolide completely inhibited mycelial growth at 0.5 to $1.0 \mu \mathrm{g} / \mathrm{ml}$, with $\mathrm{EC}_{50}$ values ranging from 0.06 to $0.15 \mu \mathrm{g} / \mathrm{ml}$ (Fig. 2). Mandipropamid inhibited mycelial growth completely at 0.25 to $0.5 \mu \mathrm{g} / \mathrm{ml}$, with
$\mathrm{EC}_{50}$ values ranging from 0.008 to $0.07 \mu \mathrm{g} / \mathrm{ml}$ (Fig. 3). Oxathiapiprolin inhibited mycelial growth completely at 0.005 to $0.01 \mu \mathrm{g} / \mathrm{ml}$. EC $\mathrm{E}_{50}$ values of oxathiapiprolin for suppressing mycelial growth ranged from 0.0002 to $0.0018 \mu \mathrm{g} / \mathrm{ml}$ (Fig. 4).

Inhibition of sporangium formation. Fluopicolide completely inhibited sporangial formation of the isolates at 1.0 to $2.5 \mu \mathrm{g} / \mathrm{ml}$, with $\mathrm{EC}_{50}$ values ranging from 0.07 to $0.4 \mu \mathrm{g} / \mathrm{ml}$ (Fig. 2). Mandipropamid inhibited mycelial growth completely at 0.1 to $0.5 \mu \mathrm{g} / \mathrm{ml}$, with $\mathrm{EC}_{50}$ values ranging from 0.005 to $0.06 \mu \mathrm{g} / \mathrm{ml}$ (Fig. 3). Oxathiapiprolin completely inhibited sporangial production at 0.001 to $0.01 \mu \mathrm{g} / \mathrm{ml}$. $\mathrm{EC}_{50}$ values for oxathiapiprolin to inhibit sporangial production ranged from 0.0001 to $0.0005 \mu \mathrm{g} / \mathrm{ml}$ (Fig. 4).

Inhibition of zoospore germination. $\mathrm{EC}_{50}$ values of fluopicolide and mandipropamid for inhibition of germination of zoospores ranged from 0.09 to 0.2 and 0.01 to $0.08 \mu \mathrm{g} / \mathrm{ml}$, respectively (Fig. 2 and 3). $\mathrm{EC}_{50}$ values for oxathiapiprolin to inhibit germination of zoospores ranged from 0.0005 to $0.004 \mu \mathrm{g} / \mathrm{ml}$ (Fig. 4).

\section{Discussion}

Black shank of tobacco remains a serious disease causing significant plant death and yield reduction. Selected use of effective fungicides is important for developing integrated programs for managing the disease. In addition to mefenoxam and metalaxyl, which have been used for black shank management in the past decades, several new fungicides have become available in recent years for black shank and other diseases caused by oomycetes, including fluopicolide, mandipropamid, and oxathiapiprolin. Little information is available regarding sensitivity of $P$. nicotianae from tobacco to these newer fungicides. In this study, effects of fluopicolide, mandipropamid, and oxathiapiprolin on growth and sporulation of $P$. nicotianae isolates from tobacco in Georgia were determined, which indicated that these compounds effectively inhibited mycelial growth, sporangial production, and germination of zoospores of the isolates. This study provides useful information for understanding mechanisms of the fungicides in reduction of black shank on tobacco.

The Fungicide Resistance Action Committee (FRAC) classifies fungicides into different groups according to their mode of action. Fluopicolide (pyridinylmethyl-benzamide, FRAC group 43) acts by delocalization of spectrin-like proteins (Krämer and Schirmer 2008). Studies conducted in recent years indicated that applications of fluopicolide reduced black shank on tobacco significantly under field conditions in the United States (Johnson 2015; Mila and Radcliff 2013). There are no refereed publications regarding effects of fluopicolide on different life stages of $P$. nicotianae from tobacco. Results in the present study showed that fluopicolide was effective in suppressing various asexual life stages of the pathogen, with mean $\mathrm{EC}_{50}$ values for mycelial growth, sporangial production, and zoospore germination at $0.09,0.15$, and $0.16 \mu \mathrm{g} / \mathrm{ml}$, respectively.

Mandipropamid (mandelic acid amide, FRAC group 40) affects cellulose synthase (Krämer and Schirmer 2008). Application of mandipropamid in combination with mefenoxam was more effective in reducing incidence of black shank on tobacco compared with mefenoxam used alone (Mila and Radcliff 2013). Effects of mandipropamid on growth and sporulation of $P$. nicotianae isolates from tobacco in the United States are unknown. A study with $P$. nicotianae isolates from tobacco in China indicated that mandipropamid was active in inhibiting sporangium production, mycelium growth, and zoospore germination of the isolates, with $\mathrm{EC}_{50}$ values of $0.009,0.011$, and $0.014 \mu \mathrm{g} / \mathrm{ml}$, respectively (Wang et al. 2013b). In the present study, mandipropamid suppressed sporangium production, mycelium growth, and zoospore germination of the isolates with average $\mathrm{EC}_{50}$ values of $0.03,0.04$, and $0.04 \mu \mathrm{g} / \mathrm{ml}$, respectively, which were three to four times higher than those for the isolates from China. Average $\mathrm{EC}_{50}$ values of mandipropamid for inhibiting mycelium growth, sporangial production, and zoospore germination of $P$. nicotianae isolates from Georgia were 2.6 to 4.3 times lower compared with fluopicolide.

Oxathiapiprolin is a piperidinyl-thiazole isoxazoline (FRAC group U15) and its mode of action is inhibiting oxysterol-binding proteins (FRAC 2016; Tally et al. 2015). Application of oxathiapiprolin 
reduced black shank on tobacco significantly under field conditions (Bittner and Mila 2016; Ji et al. 2014; Johnson 2015). The effect of oxathiapiprolin on growth and sporulation of four $P$. nicotianae isolates in North Carolina was studied (Bittner and Mila 2016). $\mathrm{EC}_{50}$ values for sporangium production, mycelium growth, and germination of zoospores averaged $0.0007,0.004$, and $0.004 \mu \mathrm{g} / \mathrm{ml}$, respectively. These are similar to ranges of the compound on isolates of $P$. nicotianae in Georgia, with average $\mathrm{EC}_{50}$ values of 0.0002 , 0.001 , and $0.0015 \mu \mathrm{g} / \mathrm{ml}$ for sporangium production, mycelium growth, and germination of zoospores, respectively. Oxathiapiprolin inhibited the isolates in Georgia at lower concentrations than fluopicolide and mandipropamid, i.e., 96 to 610 times lower than

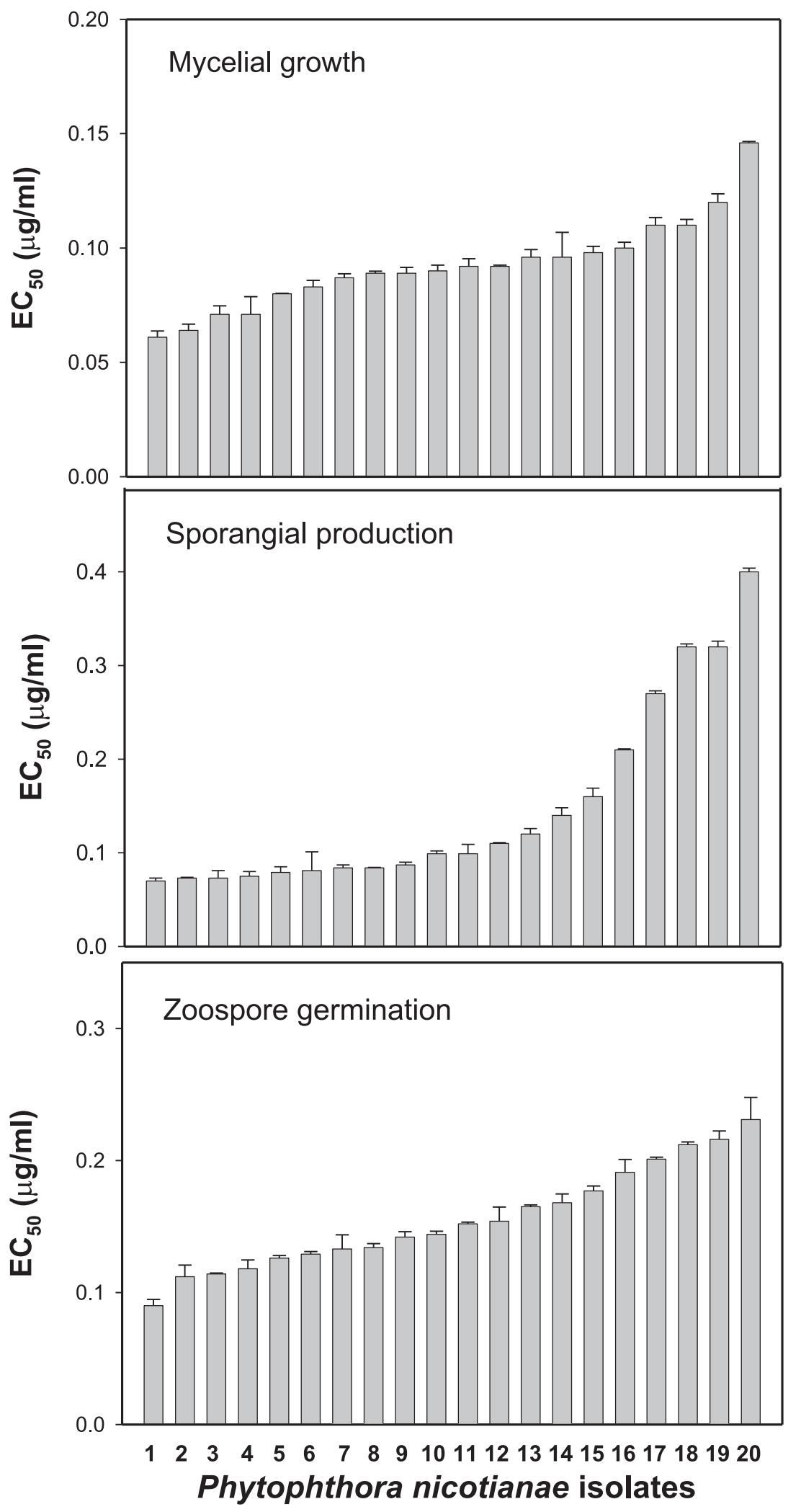

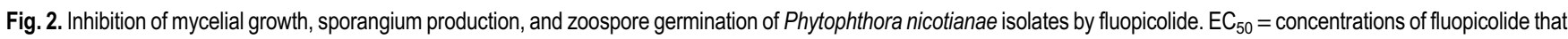
inhibited mycelial growth, sporangial formation, or zoospore germination by $50 \%$. Error bars are standard errors of the means of two experiments. 
fluopicolide and 24 to 143 times lower than mandipropamid in suppressing mycelial growth, sporangial production, and zoospore germination. One of the $P$. nicotianae isolates from tobacco tested in North Carolina grew on agar medium with $1 \mu \mathrm{g} / \mathrm{ml}$ of oxathiapiprolin (Bittner and Mila 2016); however, none of the isolates in Georgia could do so at 1 or $5 \mu \mathrm{g} / \mathrm{ml}$.
Mefenoxam has been the commonly used fungicide for managing black shank on tobacco (Antonopoulos et al. 2010; Csinos and Minton 1983; Ji et al. 2014). Studies indicated that $P$. nicotianae isolates from tobacco were sensitive to mefenoxam (Csinos and Bertrand 1994; Parkunan et al. 2010; Shew 1985; van Jaarsveld et al. 2002; Wang et al. 2013a). Although P. nicotianae isolates from tobacco with

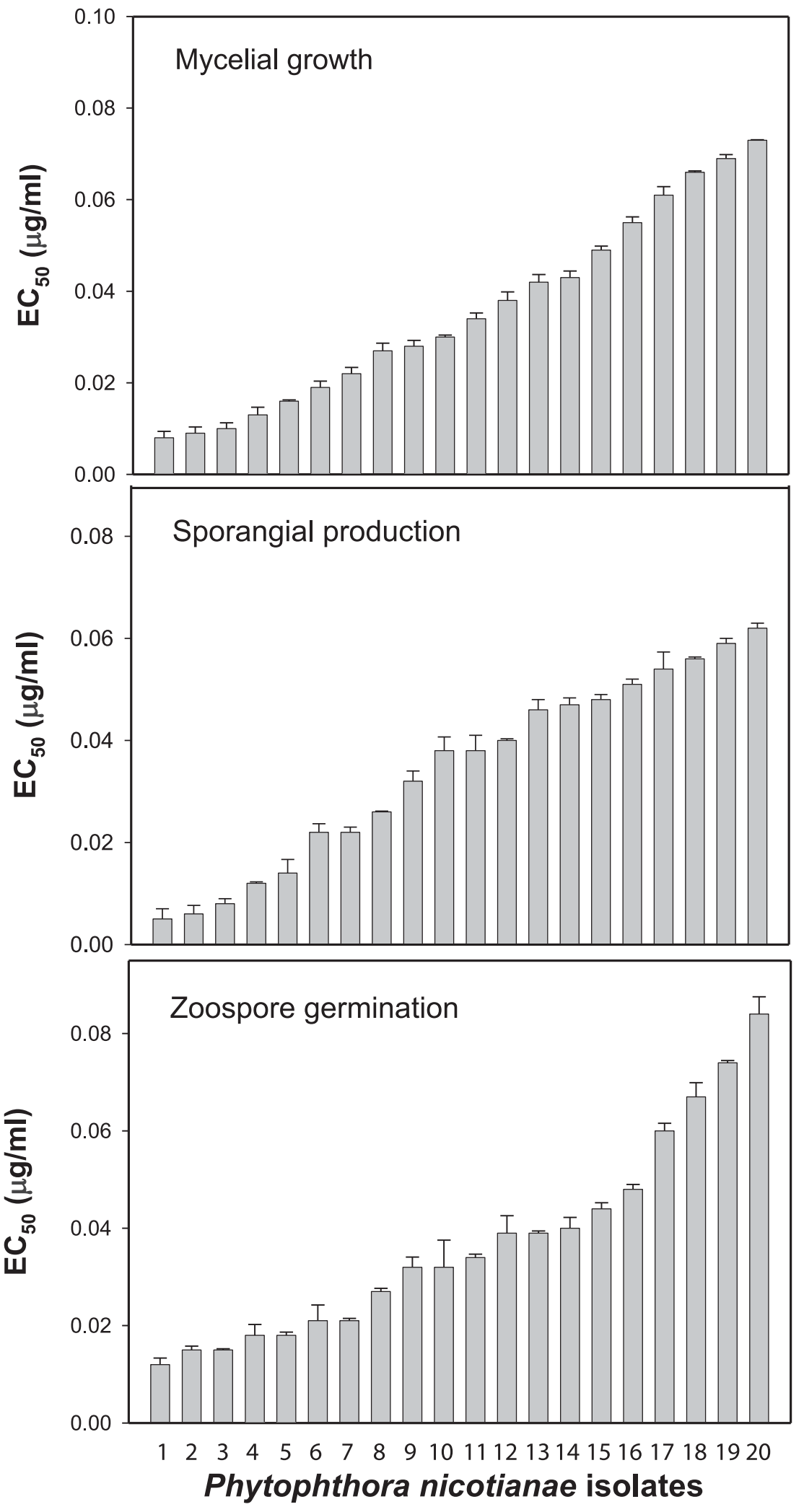

Fig. 3. Inhibition of mycelial growth, sporangium production, and zoospore germination of Phytophthora nicotianae isolates by mandipropamid. $\mathrm{EC}_{50}=\mathrm{concentrations}$ of mandipropamid that inhibited mycelial growth, sporangial formation, or zoospore germination by $50 \%$. Error bars are standard errors of the means of two experiments. 
resistance to mefenoxam have not been documented, applications of different fungicides in rotation are recommended to reduce the risk for the pathogen to potentially develop fungicide resistance. So far studies on sensitivity of $P$. nicotianae from tobacco to mefenoxam have focused on suppression of mycelial growth by the compound. Results of the present study showed that oxathiapiprolin, mandipropamid, and fluopicolide inhibited mycelial growth of $P$. nicotianae isolates at lower concentrations than mefenoxam.

In summary, results from this study indicated that oxathiapiprolin, mandipropamid, and fluopicolide were effective in suppressing mycelium growth, sporangial production, and zoospore germination of $P$. nicotianae from tobacco in Georgia. None of the $P$. nicotianae

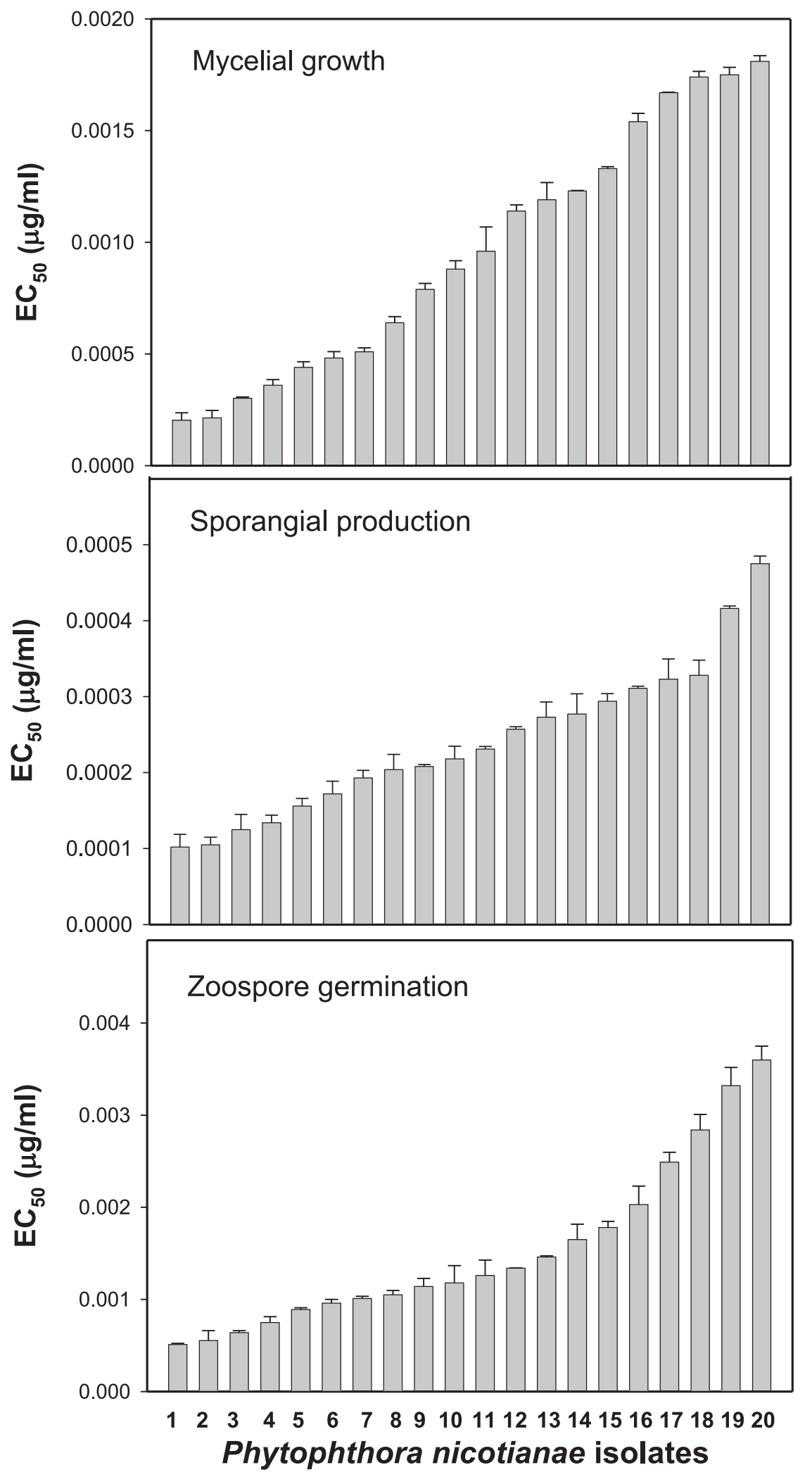

Fig. 4. Inhibition of mycelial growth, sporangium production, and zoospore germination of Phytophthora nicotianae isolates by oxathiapiprolin. $\mathrm{EC}_{50}=\mathrm{concentrations}$ of oxathiapiprolin that inhibited mycelial growth, sporangial formation, or zoospore germination by $50 \%$. Error bars are standard errors of the means of two experiments. 
isolates evaluated were resistant to the fungicides, suggesting that they could be incorporated in integrated programs for managing black shank. Information on resistance of Phytophthora spp. to fluopicolide, mandipropamid, and oxathiapiprolin is limited. The potential of resistance development to fluopicolide is unknown; however, risk of resistance to oxathiapiprolin is assumed to be medium to high, and the risk is low to medium for cross resistance to mandipropamid (FRAC 2016). Hence, resistance management is needed and future research may be conducted to monitor potential resistance development in the pathogen populations to the fungicides. Results from the present study provide valuable information about sensitivity of $P$. nicotianae to the three fungicides, which can be used as a benchmark for determining fungicide resistance development of the pathogen in future studies.

\section{Acknowledgments}

The authors are grateful to DuPont USA and Valent USA for providing products used in the study.

\section{Literature Cited}

Antonopoulos, D. F., Melton, T., and Mila, A. L. 2010. Effects of chemical control, cultivar resistance, and structure of cultivar root system on black shank incidence of tobacco. Plant Dis. 94:613-620.

Bittner, R. J., and Mila, A. L. 2016. Effects of oxathiapiprolin on Phytophthora nicotianae, the causal agent of black shank of tobacco. Crop Prot. 81:57-64.

Csinos, A. S., and Bertrand, P. F. 1994. Distribution of Phytophthora parasitica var. nicotianae races and their sensitivity to metalaxyl in Georgia. Plant Dis. 78:471-474.

Csinos, A. S., and Minton, N. A. 1983. Control of tobacco black shank with combinations of systemic fungicides and nematicides or fumigants. Plant Dis. 67:204-207.

Erwin, D. C., and Ribeiro, O. K. 1996. Phytophthora nicotianae. Pages 391-407 in: Phytophthora Diseases Worldwide. APS Press, St. Paul, MN.

FRAC. 2016. FRAC Code List: Fungicides sorted by mode of action. Published online. http://www.frac.info/docs/default-source/publications/frac-code-list/fraccode-list-2016.pdf?sfvrsn=2.

Hu, J., Hong, C., Stromberg, E. L., and Moorman, G. W. 2007. Effects of propamocarb hydrochloride on mycelial growth, sporulation, and infection by Phytophthora nicotianae isolates from Virginia nurseries. Plant Dis. 91:414-420.

Ji, P., Csinos, A. S., Hickman, L. L., and Hargett, U. 2014. Efficacy and application methods of oxathiapiprolin for management of black shank on tobacco. Plant Dis. 98:1551-1554

Johnson, C. S. 2015. Comparing fluopicolide and oxathiapiprolin with mefenoxam to manage Phytophthora nicotianae on tobacco in 2011-2015. Page 24 in Abstracts of 1st International Soilborne Oomycete Conference December 2015, Duck Key, FL, U.S.A., A. Csinos P. Ji, and P. D. Roberts, eds.
Koné, D., Csinos, A. S., Jackson, K. L., and Ji, P. 2009. Evaluation of systemic acquired resistance inducers for control of Phytophthora capsici on squash. Crop Prot. 28:533-538.

Krämer, W., and Schirmer, U. 2008. Modern Crop Protection Compounds. WileyVCH Verlag GmbH \& Co. KGaA, Weinheim, Germany.

Lucas, G. B. 1975. Diseases of Tobacco, 3rd Ed. Biological Consulting Associates, Raleigh, NC.

Matheron, M. E., and Porchas, M. 2000. Impact of azoxystrobin, dimethomorph, fluazinam, fosetyl-Al, and metalaxyl on growth, sporulation, and zoospore cyst germination of three Phytophthora spp. Plant Dis. 84:454-458.

Meng, J., and Wang, Y. 2010. Rapid detection of Phytophthora nicotianae in infected tobacco tissues and soil samples based on its Ypt1 gene. J. Phytopathol. 158:1-7.

Mila, A., and Radcliff, J. 2008. Managing Diseases. Pages 140-174 in: Tobacco Information 2009, Bull. North Carolina Cooperative Extension Service, Raleigh.

Mila, A., and Radcliff, J. 2013. Evaluation of new fungicides for control of black shank in tobacco, 2012. Plant Dis. Manage. Rep. 7:FC078.

Parkunan, V., and Ji, P. 2013. Isolation of Pythium litorale from irrigation ponds used for vegetable production and its pathogenicity on squash. Can. J. Plant Pathol. 35:415-423.

Parkunan, V., Johnson, C. S., Bowman, B. C., and Hong, C. X. 2010. Population structure, mating type, and mefenoxam sensitivity of Phytophthora nicotianae in Virginia tobacco fields. Plant Dis. 94:1361-1365.

Shew, H. D. 1985. Response of Phytophthora parasitica var. nicotianae to metalaxyl exposure. Plant Dis. 69:559-562.

Shew, H. D., and Lucas, G. B. 1998. Compendium of Tobacco Diseases,2nd ed. APS Press, St. Paul, MN.

Stein, J. M., and Kirk, W. W. 2003. Variations in the sensitivity of Phytophthora infestans isolates from different genetic backgrounds to dimethomorph. Plant Dis. 87:1283-1289.

Tally, A., Kuhn, P., Haskell, J., and Druebbisch, B. 2015. Oxathiapiprolin, a new tool for control of soil-borne Phytophthora diseases. Page 31 in Abstracts of 1st International Soilborne Oomycete Conference December 2015, Duck Key, FL, U.S.A., A. Csinos P. Ji, and P. D. Roberts, eds.

van Jaarsveld, E., Wingfield, M. J., and Drenth, A. 2002. Evaluation of tobacco cultivars for resistance to races of Phytophthora nicotianae in South Africa. J. Phytopathol. 150:456-462.

Wang, H., Chen, X., Cai, L., Cao, Y., Lu, N., Xia, H., Wang, M., and Shang, S 2013a. Race distribution and distribution of sensitivities to mefenoxam among isolates of Phytophthora parasitica var. nicotianae in Guizhou province of China. Crop Prot. 52:136-140.

Wang, H., Yang, S., Wang, M., Xia, H., Li, W., Zhang, H., Cao, Y., Lu, N., Shang, S., and Shi, J. 2013b. Sensitivity of Phytophthora parasitica to mandipropamid: In vitro determination of baseline sensitivity and in vivo fungitoxicity. Crop Prot. 43:251-255.

Yin, J., Jackson, K. L., Candole, B. L., Csinos, A. S., Langston, D. B., and Ji, P. 2012. Aggressiveness and diversity of Phytophthora capsici on vegetable crops in Georgia. Ann. Appl. Biol. 160:191-200. 